\title{
Mast Cell Count
}

National Cancer Institute

\section{Source}

National Cancer Institute. Mast Cell Count. NCI Thesaurus. Code C111246.

The determination of the amount of mast cells present in a sample. 